\title{
SPACE VARIABILITY OF PHENOLOGICAL INDICATORS OF COMMON BEAN CROP
}

\author{
VARIABILIDADE ESPACIAL DOS ÍNDICES FENOLÓGICOS DA CULTURA DO \\ FEIJÃO
}

\section{Job Teixeira de OLIVEIRA'; Morel de Passos e CARVALHO²; Cassiano Garcia ROQUE'; Fabio Henrique Rojo BAIO' ${ }^{1}$; Karina Marie KAMIMURA ${ }^{1}$; Isabela da Silva RIBEIRO'; Paulo Eduardo TEODORO ${ }^{1 *}$}

1. Universidade Federal de Mato Grosso do Sul, Campus de Chapadão do Sul, Chapadão do Sul, MS, Brasil; 2. Universidade Estadual Paulista Julio de Mesquita Filho, Campus de Ilha Solteira, Ilha Solteira, SP, Brasil. *: eduteodoro@ hotmail.com

\begin{abstract}
Common bean (Phaseolus vulgaris L.) has a representative agricultural holding, not only for the economic value of its production, but also for the large area of growing in Brazil. In the harvest 2016/17, this work was conducted in a Quartzarenic Neosol in the municipality of Cassilândia, MS. The objective of this work was to characterize the structure and magnitude of the spatial distribution of phenological indices of the common bean crop and to map the phenological indices in order to visualize the spatial distribution and to evaluate the spatial correlation among common bean yield and plant variables: grain yield (YIE), mass of one hundred grains (MHG), number of grains per plant (NG), number of grains per pod (NGP), number of pods per plant (NP), dry matter (DM), plant length (PL) and stem diameter (SD), sampled in a grid of 117 georeferenced points (81 points of base grid and 36 points of higher density grid). Analysis of these data through statistical and geostatistical techniques made it possible to verify that the production and yield components presented spatial dependence. There was a positive spatial correlation among common bean yield and the mass of one hundred grains, number of grains per pod and plant length, demonstrating that they have a strong spatial dependence.
\end{abstract}

KEYWORDS: Phaseolus vulgaris L. Precision agriculture. Geostatistics. Attribute.

\section{INTRODUCTION}

Common bean (Phaseolus vulgaris L.) is grown in almost the whole national territory and is recognized as an excellent source of proteins, vitamins, minerals and fibers that nourish and reduce incidence of diseases, besides being a food component of the Brazilian diet. Considering the harvest 2016/2017, it is estimated that the total area grown with common bean will increase to 3,078 thousand hectares, $8.5 \%$ higher than the previous harvest. National production of common bean is expected to stand at 3,285.3 thousand tons being $30.7 \%$ higher than the last season (CONAB, 2017).

With the advent of the precision agriculture in Brazil, geostatistical study of soil physical properties related to common bean yield has intensified (CAMPOS et al., 2013). According to Ferraz et al. (2012), precision agriculture is a set of techniques and technologies capable of assisting the farmer to manage his crop, aiming to increase production, income gain, efficiency in fertilization techniques, harvesting and spraying, contributing to a better final quality of the product. The study of soil spatial variability as a consequent subsidy tool for applying fertilizers in floating rate is the most common technique of precision agriculture. This technique can be applied to plant phenological indices aiming at allowing more precise management of the harvesting process and the monitoring of the plant development (FERRAZ et al., 2017).

In the geostatistics scope, the study of the technique helps the computational software used in precision agriculture; That is, the data generated and adjusted from simple data interpolation (kriging) and cross-interpolation (co-kriging) among plant attributes versus another attribute serve as a basis for estimating the spatial variability of a given trait by means of another with ease of determination (MONTANARI et al., 2015). Co-kriging may be more accurate than the kriging of a single attribute when the cross-semivariogram shows dependence among any two phenological indices (TRANGMAR et al., 1985).

In the mapping of phenological indices of the common bean plant, geostatistics has been used mainly in the mapping of yield, such as observed in the works carried out by Montanari et al (2015) and Silva et al (2011). The numbers of grain per plant, pod per plant, grain per pod, mass of one hundred grains and yield of the common bean plant were mapped by Silva et al (2011). Ferraz et al (2017) mapped the length and diameter of the stem of a coffee plant. Montanari et al (2015) studied the amount of plant dry matter. The objective of this 
study was to characterize the structure and magnitude of the spatial distribution of phenological indices of the common bean crop and to map the phenological indices aiming at visualizing the spatial distribution and to evaluate the spatial correlation among common bean yield and plant traits.

\section{MATERIAL AND METHODS}

The work was developed at the irrigated area of a central pivot, under the geographical coordinates 356381.383m; 7893667.280m (UTM), in the Farm Flor Jardim, municipality of Cassilândia, MS (Figure 1). Average annual rainfall is $1500 \mathrm{~mm}$ and the average temperature is $24.2^{\circ} \mathrm{C}$. According to Köppen's classification, climatic type is Aw, characterized as tropical humid with rainy season in summer and dry in winter.

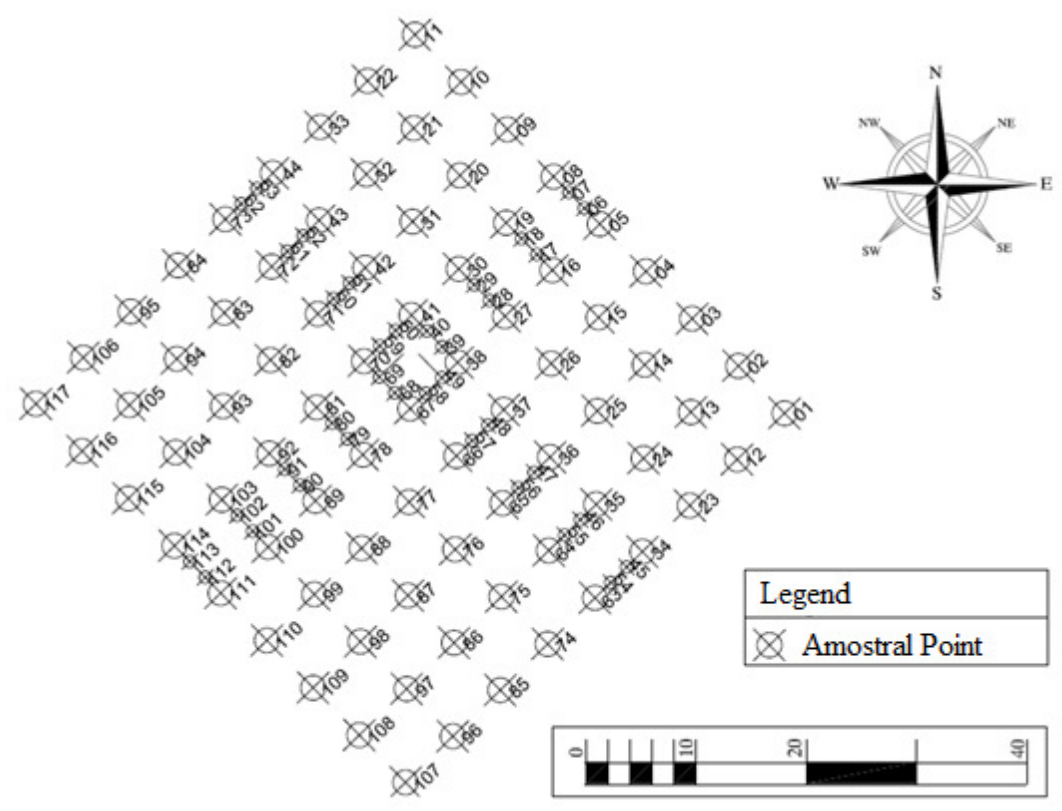

Figure 1. Sampling grid and detailing of the sampling performed at Farm Flor Jardim, Cassilândia, MS.

The soil on which the experimental grids Orthic Quartzanic Neossoil very sandy texture. The were installed was classified according to the Brazilian Soil Classification System. It is a values of the physical and chemical analyses are shown in Table 1.

Table 1. Soil chemical and physical properties of the study area.

\begin{tabular}{|c|c|c|c|c|c|c|c|c|c|c|c|c|c|c|c|}
\hline $\begin{array}{l}\text { Laye } \\
\mathrm{r}\end{array}$ & $\begin{array}{l}\text { Granu } \\
\text { Comp }\end{array}$ & $\begin{array}{l}\text { metri } \\
\text { ition }\end{array}$ & & & Chemic & al analy & & & & & & & & & \\
\hline- & sand & silt & clay & $\mathrm{pH}$ & $\mathrm{P}$ & $\mathrm{OM}$ & $\mathrm{K}^{+}$ & $\mathrm{Ca}^{+2}$ & $\mathrm{Mg}^{+2}$ & $\mathrm{H}^{+}+\mathrm{Al}^{+3}$ & $\mathrm{Al}^{+3}$ & SB & CEC & $\begin{array}{l}\mathrm{V} \\
\%\end{array}$ & $\begin{array}{l}\mathrm{m} \\
\%\end{array}$ \\
\hline $\mathrm{m}$ & $\begin{array}{l}\ldots . . . \\
. . \\
\end{array}$ & $\ldots . \mathrm{g} / \mathrm{k}$ & $\ldots .$. & $\begin{array}{l}\mathrm{CaCl} \\
2 \\
\end{array}$ & $\mathrm{mg}_{3} \mathrm{dm}$ & $\mathrm{g} / \mathrm{dm}$ & $\ldots$ & & & & & & $\ldots$. & $-\%$ & $\%-$ \\
\hline $\begin{array}{l}0 \\
0.20\end{array}$ & 946 & 11 & 43 & 5,4 & 8 & 13 & 0.2 & 17 & 8 & 13 & 0 & 25.2 & 38.2 & 66 & 0 \\
\hline $\begin{array}{l}0.20- \\
0.40\end{array}$ & 932 & 20 & 48 & 5,1 & 12 & 10 & 0.5 & 7 & 2 & 15 & 1 & 9.5 & 24.5 & 39 & 10 \\
\hline
\end{tabular}

OM: organic matter; SB: sum of bases; CEC: cation exchange capacity.

In the field of crop management, under notillage system in irrigated area, we performed only the desiccation of the weeds antecedent to the common bean, with an application of $2 \mathrm{~kg} \mathrm{ha}^{-1}$ of the herbicide glyphosate, and the management of the area for sowing was carried out between 08 and 09 July 2016. On July 10, 2016, Elite cultivar was sown at a spacing of $0.45 \mathrm{~m}$ between rows with a density of 246,914 plants per hectare. For this, the 
average amount of 11 seeds per meter was used. Harvesting was performed 100 days after sowing.

The $x$ and $y$ directions of the Cartesian coordinate system were defined and the stacking of the experimental grid was performed near the common bean maturity, i.e., at the first ten-day period of October 2016, spaced $6 \mathrm{~m}$ apart. Each experimental grid was constituted of nine transects of $48 \mathrm{~m} \mathrm{x} 48 \mathrm{~m}$. Therefore, transects were spaced 6 $\mathrm{m}$, with sample points squared at $6 \mathrm{~m} \times 6 \mathrm{~m}$, containing 81 of them. However, within the large grid, points with spacings smaller than those mentioned were spaced $2 \mathrm{~m}$ between them (grid with higher density). As in this case the total of sample points was 36, in the data grid it was 117 .

Using denser grids has the objective of refining the distance between the points to determine the reach of the spatial dependence aiming at detecting variations in smaller distances, implying a decrease of the nugget effect and hence improving a used grid (MONTANARI et al, 2013b). This type of sampling using higher density grids within a larger mesh was also used in the study conducted by Montanari et al, (2013a and 2013b).

The determined phenological indices were individually collected around each sampling point, which was usually constituted by the plant data collection positioned in the center and its surroundings. The laboratory stage of the analyses was carried out between October and December 2016. The representative area of this collection was $3.20 \mathrm{~m}^{2}$, with 4 rows of plants $(1.80 \mathrm{~m} \mathrm{x} 1.80 \mathrm{~m})$. All the plants originating from the surroundings of the staked sampling point were collected.

The evaluated phenological indices of the common bean crop were: grain yield (YIE), obtained with values transformed to the standardized conditions of $0.13 \mathrm{~kg} \mathrm{~kg}^{-1}$ of moisture content, represented by $\mathrm{kg} \mathrm{ha}^{-1}$; mass of one hundred grains (MHG), obtained by weighing one hundred random common bean grains from the sample, in $\mathrm{g}$; number of grains per plant (NG); number of grains per pod (NGP); number of pods per plant (NP); dry matter of the plant (DM) without grains, in $g$, determined by placing the plants under the sun for 10 days and when were practically dry, they were placed in a greenhouse at $650^{\circ} \mathrm{C}$ for $48 \mathrm{~h}$; plant length (PL), in $\mathrm{cm}$, dimensioned by measuring the distance from the hypocotyl to the last growth point of the plant; stem diameter (SD), in mm, which was determined by measuring the hypocotyl diameter of the plant with a digital caliper.

For each attribute studied, the classical descriptive analysis was carried out using the SAS statistical software, in which the mean, median, minimum and maximum values, standard deviation, coefficient of variation, kurtosis, asymmetry and data frequency distribution analysis were calculated. Thus, to test the normality hypothesis, or lognormality of the phenological indices (x), Shapiro and Wilk (1965) test was used at 5\% probability level. In it the statistic tests the null hypothesis, which it judges to be the sample coming from a population with normal distribution.

For characterizing the structure and magnitude of the spatial dependence of the phenological indices of the soil and common bean plant, the semivariogram and semivariance estimates were estimated by estimating the coefficients of the theoretical model for the semivariogram called the nugget effect (C0); sill (C0_C); and range (A0). After the semivariograms were adjusted, data were interpolated by kriging aiming at allowing the visualization of the spatial distribution patterns of the phenological indices in the common bean crop, through maps. Standard error maps of kriging prediction were generated. These maps refer to the standard deviation of the prediction for any individual point (CUNHA et al., 2013), and they are obtained to have the source of information about the reliability of the interpolated values in the study area (FERRAZ et al., 2015). Cross-validation is a tool to evaluate alternative models of simple and crossed semivariograms, which will perform kriging and co-kriging, respectively. In its analysis, each point contained within the spatial domain is removed individually, its value is estimated as if it did not exist. Hence, a graph of estimated versus observed values can be built for all points.

\section{RESULTS AND DISCUSSION}

Descriptive analysis data of the phenological indices of the plant under study are in Table 2. From the analysis of the minimum and maximum mean values and the values variance of the plant phenological indices where the variation is considerable in the data. However, only the knowledge of this variation is not enough to identify the places where the high values of an attribute are found, nor the places where the lower values are found. In this case, the use of geostatistics becomes necessary to identify if there is spatial variability and how this variability occurs in the study area, with the consequent elaboration of maps to allow more precise management of the necessary field interventions. 
Table 2. Descriptive statistics for the assessed variables.

\begin{tabular}{llllllllll}
$\begin{array}{l}\text { Phenological } \\
\text { Index }\end{array}$ & Mean & Minimum & Maximum & $\begin{array}{l}\text { Standard } \\
\text { deviation }\end{array}$ \\
& & & & & Variation & Kurtosis & Asymmetry & Pr<w & FD \\
\hline YIE & 1088.9 & 328.2 & 1991.7 & 340.5 & 31.3 & -0.193 & 0.197 & 0.654 & NO \\
MHG & 25.3 & 18.6 & 33.8 & 2.9 & 11.6 & -0.453 & 0.137 & 0.421 & NO \\
NG & 99.7 & 32.3 & 163.8 & 26.4 & 26.5 & 0.051 & 0.031 & 0.532 & NO \\
NGP & 5.2 & 3.6 & 6.3 & 0.5 & 10.1 & 0.019 & -0.332 & 0.114 & NO \\
NP & 18.9 & 9.3 & 29 & 4 & 21.1 & -0.123 & -0.005 & 0.702 & NO \\
DM & 8.8 & 3.4 & 14 & 2.1 & 24.3 & 0.181 & 0.061 & 0.703 & NO \\
PL & 66.6 & 35.5 & 92.5 & 11.5 & 17.3 & -0.006 & -0.345 & 0.102 & NO \\
SD & 7.5 & 6.2 & 9.3 & 0.6 & 8.3 & -0.045 & 0.246 & 0.471 & NO \\
\hline
\end{tabular}

a) YIE = grain yield, $\left(\mathrm{kg} \mathrm{ha}^{-1}\right)$, MHG = mass of one hundred grains (g); NG = number of grains per plant; NGP: number of grains per pod; $\mathrm{NP}=$ number of pods per plant; $\mathrm{DM}=$ dry matter of the plant $(\mathrm{g}) ; \mathrm{PL}=$ plant length $(\mathrm{cm}) ; \mathrm{SD}=$ stem diameter $(\mathrm{mm}) ;(\mathrm{b}) \mathrm{FD}=$ frequency distribution; $\mathrm{NO}=$ normal

In Table 2, descriptive analysis of the phenological indices studied is presented. According to Pimentel-Gomes and Garcia (2002), the variability of an attribute can be classified according to the magnitude of its coefficient of variation (CV). Their classes were determined as low $(\mathrm{CV}<10 \%)$, medium $(10 \%<\mathrm{CV}<20 \%)$, high $(20 \%<\mathrm{CV}<30 \%)$ and very high $(\mathrm{CV}>30 \%)$. Therefore, common bean grain yield (YIE) presented a very high coefficient of variation (31.3\%). Already Martins et al. (2009), when analyzing a dystroferric Red Latosol under no-tillage, in regular grids of 135 sampling points, found high variability (24\%) for grain yield in common bean. In this respect, it differed from those obtained by Megda et al. (2008) and Montanari et al. (2013b), who found values of medium variability $(19,18.3 \%)$ in a dystroferric Red Latosol under no-tillage. The traits NG, NP and DM presented high variability, with coefficients of variation of $26.5 ; 21.1$ and $24.3 \%$, respectively. Montanari et al, (2013b) also found high variability in the NG and NP, with coefficients of variation of 24.2 and $20.6 \%$, respectively. Phenological indices mass of one hundred grains (MHG), number of grains per pod (NGP) and plant length (PL) presented medium variability $(11.6,10.1$ and $17.3 \%$ respectively). At lastly, stem diameter (SD) had low variability $(8.3 \%)$. Variability rates, from medium to very high, found for most common bean production components, except SD, can be explained by the fact that the studied soil (Quartzarenic Neosol) is poor in nutrients (see Table 1), thus increasing the coefficient of variation of the phenological indices.
The study of phenological indices showed positive asymmetry coefficients for YIE, MHG, NG, DM and SD, which were respectively 0.197 ; $0.137,0.031,0.061$ and 0.246 , and negative for NGP, NP and PL, which were $-0,332,-0,005$ and 0,345 respectively. Already the positive kurtosis coefficients for NG, NGP and DM were 0.051; 0.019 and 0.181 , respectively. However, regardless of such coefficients, these phenological indices were significant at $5 \%$ probability by the Shapiro and Wilk (1965) normality test, since their respective probabilities were $0.654 ; 0.421 ; 0.5320 .114,0.702$, $0.703,0.102$ and 0.471 . Similar results for YIE, NP, NG and MHG of common bean, with normal frequency distribution, were also found by Silva et al. (2011).

Geostatistical analysis (Table 3) showed that there was a spatial dependence for the semivariograms of the phenological indices YIE, MHG and DM, which adjusted to the spherical model, whereas SD adjusted to the exponential model, agreeing with Montanari et al., (2013b), who reported that spherical and exponential models are the most common theorists of soil and plant attributes. However, phenological indices NG, NGP, NP and PL adjusted to the Gaussian model.

By the Cambardella et al. (1994) classification, it is considered as a strong spatial dependence evaluation (SDE) semivariograms having a nugget effect $<25 \%$ of the sill, moderate when it is between 25 and $75 \%$ and weak $>75 \%$. According to this classification, the values of the variables grain yield, mass of one hundred grains and stem diameter presented strong SDE, whereas 
number of grains per plant, number of grains per pod, number of pods per plant, dry matter and plant length presented moderate SDE. According to Ferraz et al, (2017), studying the spatial variability of plant phenological indices in a coffee field, found similar results, where plant height and crown diameter presented strong SDE, and yield showed weak SDE.

Table 3. Estimated parameters for the simple semivariogram of the assessed variables.

\begin{tabular}{|c|c|c|c|c|c|c|c|c|c|c|c|}
\hline \multirow{2}{*}{$\begin{array}{l}\text { Phenological } \\
\text { Index }^{(a)}\end{array}$} & \multirow{2}{*}{ (b) } & \multirow{2}{*}{ Nugget Co } & \multirow{2}{*}{$\begin{array}{l}\text { Sill } \\
\mathrm{Co}+\mathrm{C}\end{array}$} & \multirow{2}{*}{$\begin{array}{l}\text { Range } \\
\text { Ao (m) }\end{array}$} & \multirow{2}{*}{$\mathrm{r}^{2}$} & \multirow{2}{*}{$\mathrm{SSE}^{(\mathrm{c})}$} & \multicolumn{2}{|c|}{$\mathrm{SDE}^{(\mathrm{d})}$} & \multicolumn{3}{|c|}{ Cross-validation } \\
\hline & & & & & & & $\%$ & Class & $\mathrm{a}$ & $\mathrm{b}$ & $\mathrm{r}$ \\
\hline YIE & sph & $3.82 \times 10^{4}$ & $1.58 \times 10^{5}$ & 51.0 & 0.87 & $3.13 \times 10^{9}$ & 75.8 & Strong & 91.1 & 0.917 & 0.651 \\
\hline MHG & $\mathrm{sph}$ & 1.73 & 8.55 & 18.2 & 0.67 & $1.46 \times 10^{1}$ & 79.8 & Strong & -0.42 & 1.016 & 0.784 \\
\hline NG & gau & $3.58 \times 10^{2}$ & $9.45 \times 10^{2}$ & 48.0 & 0.75 & $1.55 \times 10^{5}$ & 62.1 & Mo & 4.97 & 0.947 & 0.582 \\
\hline NGP & gau & 0.19 & 0.3 & 47.0 & 0.84 & $5.50 \times 10^{-3}$ & 45.7 & Moderate & 0.47 & 0.910 & 0.451 \\
\hline NP & gau & 8.46 & $2.00 \times 10^{1}$ & 46.4 & 0.52 & $1.86 \times 10^{2}$ & 57.8 & Moderate & 0.3 & 0.984 & 0.564 \\
\hline $\mathrm{DM}$ & sph & 2.88 & 5.4 & 49.1 & 0.8 & 1.51 & 46.7 & Moderate & 1.04 & 0.882 & 0.362 \\
\hline PL & gau & $6.50 \times 10^{1}$ & $1.89 \times 10^{2}$ & 47.3 & 0.78 & $5.02 \times 10^{3}$ & 65.6 & Moderate & 3.13 & 0.954 & 0.557 \\
\hline SD & $\exp$ & $4.9 \times 10^{-2}$ & 0.397 & 4.8 & 0.49 & $2.65 \times 10^{-3}$ & 87.7 & Strong & 0.89 & 0.280 & 0.283 \\
\hline
\end{tabular}

a) YIE = grain yield, $\left(\mathrm{kg} \mathrm{ha}^{-1}\right)$, MHG = mass of one hundred grains $(\mathrm{g})$; NG = number of grains per plant; NGP: number of grains per pod; $\mathrm{NP}=$ number of pods per plant; $\mathrm{DM}=$ dry matter of the plant $(\mathrm{g}) ; \mathrm{PL}=$ plant length $(\mathrm{cm}) ; \mathrm{SD}=$ stem diameter $(\mathrm{mm}) ;(\mathrm{b}) \mathrm{sph}=$ spherical and gau = Gaussian; (c) SSE = sum of squared errors; (d) SDE = space dependency evaluator.

Range values for semivariograms have considerable importance in determining the spatial dependence limit, which may also be indicative of the interval between soil mapping units (TRANGMAR et al.,1985) or phenological indices related to plants (FERRAZ et al., 2012). The range found by the variables was from $4.8 \mathrm{~m}$ (stem diameter) to $51.0 \mathrm{~m}$ (grain yield) (Figure 2). Therefore, under the conditions of this study, aiming at supporting future research, in which the same phenological indices are involved, we suggested that the values of the ranges to be used in the geostatistical packages that will feed the computational packages used in precision agriculture, overall, should not be smaller than 4.8 m.

After adjusting the semivariograms for each plant variable, values of the phenological indices were estimated using ordinary kriging. In this way, it was possible to build spatial distribution maps for all variables of this study (Figures 3a, 3b, 3c, 3d, 3e, $3 \mathrm{f}, 3 \mathrm{~g}$ and $3 \mathrm{~h}$ ), which allowed visualizing the spatial variability in the area.

When analyzing the spatial variability map of the yield, it was possible to notice that the southern and southeastern regions of the area presented the highest yields of the crop. The lowest yield was observed in the northern region and in the northeast portion The observation of a yield map (Figure 3a), together with the observation of other types of maps, such as the plant phenological indices, can contribute to find reasons for the occurrence of yield variability, especially in the case of low yield, which will make it possible to correct the flaws, allowing in the next harvest these problems can be minimized. In this way, the farmer can take advantage of the historical area information from previous mappings to take the decisions necessary for the good progress of the crop, identifying regions that have a greater or lesser need for intervention in both soil and crop. These maps can also be used in harvest management, as they will contribute to the yield estimation, logistics and determination of the point of harvester unloading, which can reduce unnecessary stops and maneuvers. (FERRAZ et al., 2015). 


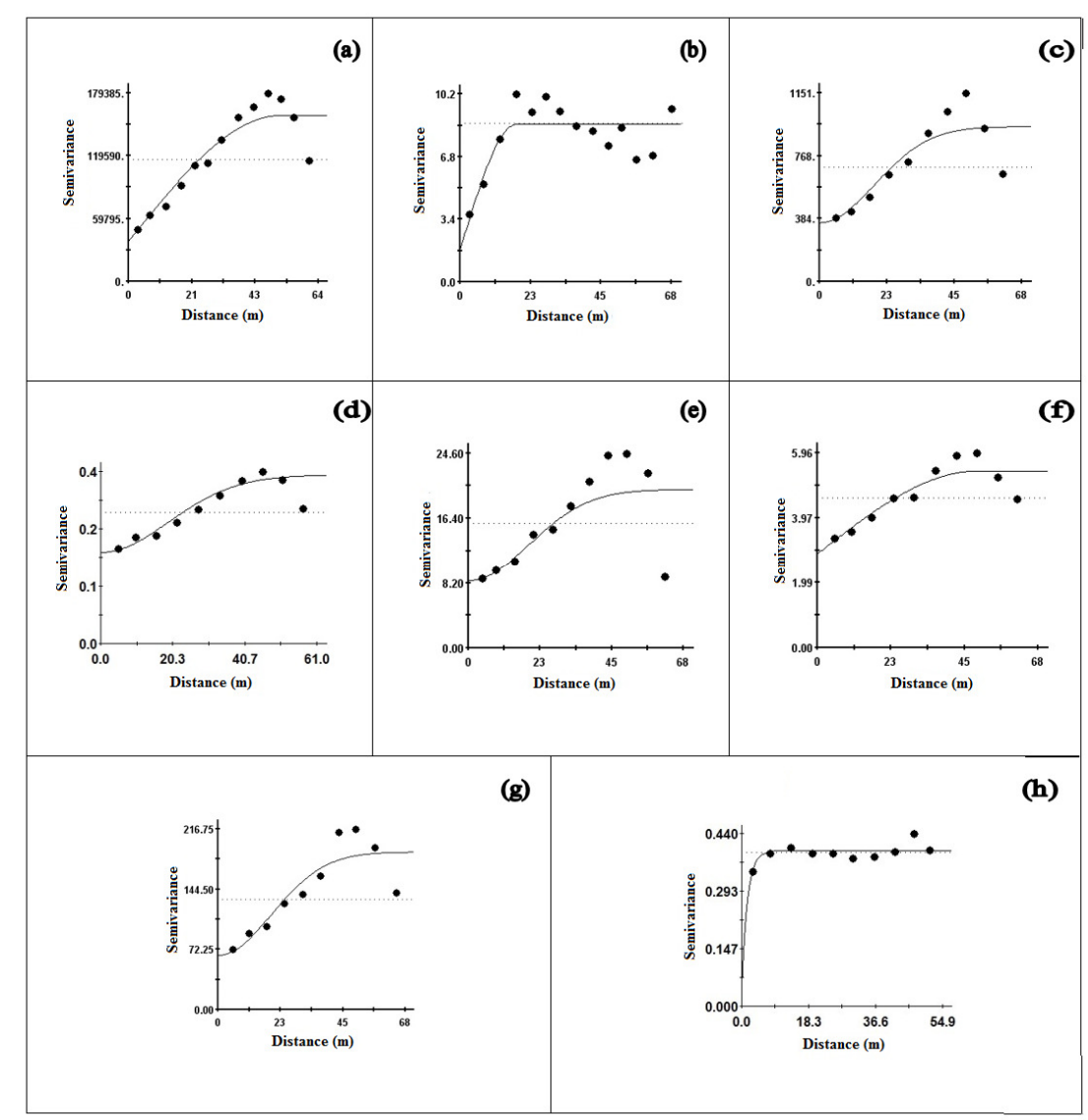

Figure 2. Semivariograms of the plant phenological indices of the common bean, where: (a) grain yield; (b) mass of one hundred grains; (c) number of grains per plant; (d) number of grains per pod; (e) number of pods per plant; (f) dry matter of one plant at sampling point; (g) plant length of one plant at sampling point; (h) stem diameter of one plant at sampling point.

According to the spatial distribution map of the MHG (Figure 3b), most of the area is classified as low grain weight, mainly in the north, northeast and east. The highest grain weight is observed in the southeast, central and northwest regions. This indicative is important for the farmer, well and weight proportional to the grain size, and reflects in the classification of the separation sieve. A standardized mass of grains is more commercialized and, mainly, allows a sowing with adequate distribution of grains, if it is used as seed, an important component to obtain greater yields.

Common bean with number of grains per plant evidenced that the southern and southeastern regions presented the highest yields of the crop. The lowest yield was observed in the northern region and in the northeast portion of the area. The same was observed in the number of pods per plant. Features equal to yield. Analyzing the map of grains per pod, we observed that the southern, southeastern, southwest and part of the west presented the highest yields. The lowest values of grains per pod were observed in the north and in the northeast regions.

Plant dry matter indicates greater mass as well as yield in part of the south and southeast regions of the map. The other regions ranged between medium and low dry matter production. The value of this attribute studied, according to Concenço et al, (2013) indicates that the planted crop should be followed by sowing of species that provide high amount of residual dry matter in the off-season, with uniform distribution on the soil surface. Moreover, in recent years there has been a prolonged period of drought over the sowing of soybeans in the Cerrado region, causing problems of germination and development of this crop. Recent works have shown that the sowing of the crop under stands with high concentration of dry matter provides good conditions and reduces the problems mentioned above.

Plant length is an important plant growth trait that indicates its development. This trait is closely related to the management imposed on the crop. In this way, identifying the spatial variability 
of this phenological index and its consequent mapping can collaborate with the farmers in the identification of distortions that are occurring in the field, allowing its correction. The highest plant length values could be observed in the eastern, central, west, southeast, southwest and south portions (Figure 3g) and the lowest values identified in the northeast and north. For the stem diameter, Figure $3 \mathrm{~h}$, the highest values were identified in the central, southeastern, and southern, and the lowest values were found in the southern and western portions.

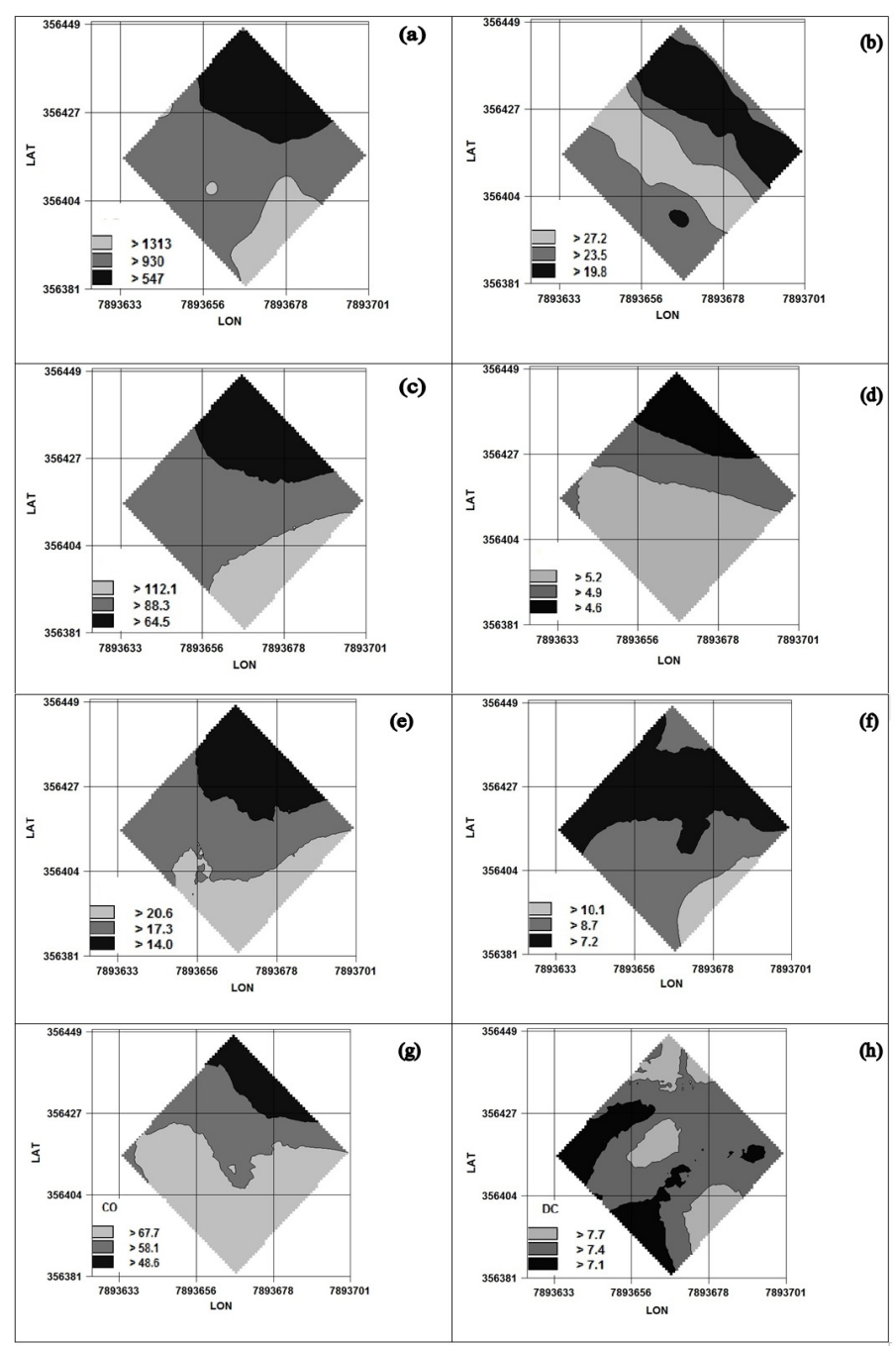

Figure 3. Simple kriging maps of plant phenological indices of common bean where: (a) grain yield; (b) mass of one hundred grains; (c) number of grains per plant; (d) number of grains per pod; (e) number of pods per plant; (f) dry matter of one plant at sampling point; (g) plant length of one plant at sampling point; (h) stem diameter of one plant at sampling point.

Table 3 shows the cross-validation parameters for kriging of yield and plant phenological indices. Their decreasing relationship, analyzed by the magnitude of the correlation coefficient (r), was as follows:1) MHG (0.784), 2) YIE (0.651), 3) NG (0.582), 4) NP (0.564), 5) PL (0.557), 7), 6) NGP (0.452), 7) DM (0.362) and 8) SD (0.283). Thus, the three-best cross-validations were established for the MHG, YIE and NG, whose correlation coefficients ranged from 0.784 to 0.582 . On the other hand, the angular coefficients (b) of cross-validations ranged from 1.016 (MHG) to
0.280 (SD). Cross-validation measures the confidence of the interpolated values in which it was possible to observe that the largest errors for all variables under study are in the border of the area, and in the places closest to the sampling points there is the smaller standard errors. In this way, it is observed that the map estimates of Figures 3a, 3b, $3 \mathrm{c}, 3 \mathrm{~d}, 3 \mathrm{e}, 3 \mathrm{f}, 3 \mathrm{~g}$ and $3 \mathrm{~h}$ were well performed, because the errors were relatively low in relation to the variations presented by the already described phenological indices. 
Table 4. Estimated parameters for the cross-semivariogram of the assessed variables.

\begin{tabular}{|c|c|c|c|c|c|c|c|c|}
\hline \multirow{2}{*}{$\begin{array}{l}\text { Phenological } \\
\text { Index }^{\text {(a) }}\end{array}$} & \multirow{2}{*}{ Model $^{(\mathrm{b})}$} & \multirow{2}{*}{ Nugget Co } & \multirow{2}{*}{ Sill Co+C } & \multirow{2}{*}{$\begin{array}{l}\text { Range } \\
\text { (m) }\end{array}$} & \multirow{2}{*}{${ }^{A o} r^{2}$} & \multirow{2}{*}{$\mathrm{SSE}^{(\mathrm{c})}$} & \multicolumn{2}{|c|}{$\mathrm{SDE}^{(\mathrm{d})}$} \\
\hline & & & & & & & $\%$ & Class \\
\hline $\mathrm{YIE}=\mathrm{f}(\mathrm{MHG})$ & $\mathrm{sph}$ & $9.20 \times 10^{1}$ & $6.17 \times 10^{2}$ & 29.0 & 0.829 & $3.83 \times 10^{4}$ & 85.1 & Strong \\
\hline $\mathrm{YIE}=\mathrm{f}(\mathrm{NG})$ & gau & $3.74 \times 10^{3}$ & $1.27 \times 10^{4}$ & 49.9 & 0.929 & $7.30 \times 10^{6}$ & 70.6 & Moderate \\
\hline $\mathrm{YIE}=\mathrm{f}(\mathrm{NGP})$ & gau & $4.22 \times 10^{1}$ & $1.89 \times 10^{2}$ & 51.3 & 0.928 & $1.93 \times 10^{3}$ & 77.7 & Strong \\
\hline YIE $=f(N P)$ & gau & $5.37 \times 10^{2}$ & $1.86 \times 10^{3}$ & 50.4 & 0.939 & $1.34 \times 10^{5}$ & 71.1 & Moderate \\
\hline$Y I E=f(D M)$ & gau & $2.26 \times 10^{2}$ & $6.11 \times 10^{2}$ & 44.3 & 0.846 & $3.33 \times 10^{4}$ & 63 & Moderate \\
\hline YIE $=f(P L)$ & gau & $6.30 \times 10^{2}$ & $4.30 \times 10^{3}$ & 52.7 & 0.962 & $6.12 \times 10^{5}$ & 85.3 & Strong \\
\hline $\mathrm{YIE}=\mathrm{f}(\mathrm{SD})$ & gau & $2.45 \times 10^{1}$ & $6.00 \times 10^{1}$ & 9.5 & 0.605 & $5.60 \times 10^{2}$ & 59.2 & Moderate \\
\hline
\end{tabular}

(a) YIE = grain yield, in function $\mathrm{f}(\mathrm{MHG})=$ mass of one hundred grains, $f(\mathrm{NG})$ number of grains per plant, $f(\mathrm{NGP})=$ number of grains per pod, $f(N P)=$ number of pods per plant, $f(D M)=$ dry matter o at sampling point, $f(P L)=$ plant length at sampling point, $(b)$ sph $=$ spherical and gau = Gaussian; (c) SSE = sum of squared errors; (d) SDE = space dependency evaluator.

When the cross-semivariogram was performed between plant phenological indices, there were positive spatial correlations (Table 4) for YIE $=\mathrm{f}(\mathrm{MHG})$ (mass of one hundred grains), YIE $=\mathrm{f}$ $(\mathrm{NGP}), \mathrm{YIE}=\mathrm{f}(\mathrm{SDE}=85.1,77.7$ and $85.3 \%$ respectively), and spherical adjusted model for YIE $=\mathrm{f}(\mathrm{MHG})$ and Gaussian model for YIE $=\mathrm{f}(\mathrm{NGP})$ and $\mathrm{YIE}=\mathrm{f}(\mathrm{PL})$. All other spatial dependencies studied presented moderate SDE, and the values of the cross-semivariogram between yield and phenological indices were: $\mathrm{YIE}=\mathrm{f}(\mathrm{NG}), \mathrm{YIE}=\mathrm{f}(\mathrm{NP})$ and $\mathrm{YIE}=\mathrm{f}(\mathrm{DM})$, which presented spatial dependence and gaussian adjustment models. Silva et al (2011) found strong spatial dependency among common bean yield in terms of pods per plant (YIE $=\mathrm{f}(\mathrm{NP})$ ) with a coefficient of determination $\mathrm{r}^{2}$ of 0.781, SDE $97.9 \%$ and spherical adjusted model.

These results show a direct relationship among the yield and the production components studied, i.e., with the increased plant growth there is an increase in grain yield, disagreeing with the study carried out by Soratto et al. (2015), who stated that excessive shoot growth of the common bean can to increase the lodging and to promote very fast closure of the crop, limiting grain yield. Spatial coefficient of determination $\left(\mathrm{r}^{2}\right)$ was: $\mathrm{YIE}=\mathrm{f}(\mathrm{NP})$
(0.939); YIE=f(NG) (0.929); YIE=f(NGP) (0.928); $\mathrm{YIE}=\mathrm{f}(\mathrm{PL}) \quad(0.962) ; \quad \mathrm{YIE}=\mathrm{f}(\mathrm{DM}) \quad$ (0.846); $\mathrm{YIE}=\mathrm{f}(\mathrm{MHG})$ (0.829), higher than 0.800. Already their decreasing relationship analyzed by the greatness of the range (Ao) was as follows: $\mathrm{YIE}=\mathrm{f}(\mathrm{PL}) \quad(52.7) \quad \mathrm{m} ; \quad \mathrm{YIE}=\mathrm{f}(\mathrm{NGP}) \quad$ (51.3) $\mathrm{m}$; $\mathrm{YIE}=\mathrm{f}(\mathrm{NP}) \quad(50.4) \quad \mathrm{m} ; \quad \mathrm{YIE}=\mathrm{f}(\mathrm{NG}) \quad$ (49.9) $\mathrm{m}$; $\mathrm{YIE}=\mathrm{f}(\mathrm{DM})(44,3) \mathrm{m}$ and $\mathrm{YIE}=\mathrm{f}(\mathrm{MHG})(29.0) \mathrm{m}$. Thus, there was a significant linear correlation among YIE and other phenological indices of the common bean, with satisfactory semivariographic adjustments. Therefore, analyzing the Table 4 , it can be inferred, for example, that the plant length appeared as a good indicator of common bean yield when intended for estimation of yield in cerrado soil.

\section{CONCLUSION}

Production and yield common bean components presented spatial dependence. There was a positive spatial correlation among common bean yield and the mass of one hundred grains, number of grains per pod and plant length, demonstrating that they have a strong spatial dependence.

RESUMO: A cultura do feijoeiro (Phaseolus vulgaris L.) tem representativa exploração agrícola, não só pelo valor econômico de sua produção, como também pela grande área de cultivo no Brasil. No ano agrícola de 2016/17, este trabalho foi conduzido em um Neossolo Quartzarênico no município de Cassilândia, MS. O trabalho objetivou caracterizar a estrutura e a magnitude da distribuição espacial de índices fenológicos da planta em lavoura de feijão e realizar o mapeamento desses índices fenológicos, de forma a visualizar a distribuição espacial, e avaliar a correlação espacial existente entre a produtividade do feijoeiro e as variáveis da planta: produtividade de grãos (PG), massa de cem grãos 
(MC), número de grãos por uma planta (GP), número de grãos por uma vagem (GV), número de vagem por uma planta (VP), massa seca de uma planta (MS), comprimento da planta (CO), diâmetro do colmo (DC), amostrados em uma malha de 117 pontos georreferenciados ( 81 pontos da malha base e 36 pontos de malha com maior densidade). A análise destes dados por meio das técnicas estatísticas e da geoestatística possibilitaram constatar que os componentes de produção e produtividade do feijão apresentaram dependência espacial. Houve destaque na correlação espacial positiva entre a produtividade do feijoeiro e a massa de cem grãos, grãos por vagem e comprimento da planta, demonstrando que as mesmas possuem uma dependência espacial forte.

PALAVRAS-CHAVE: Phaseolus vulgaris L. Agricultura de precisão. Geoestatística. Atributo.

\section{REFERENCES}

CAMBARDELlA, C. A.; MOORMAN, T. B.; NOVAK, J. M.; PARKIN, T. B.; KARLEN, D. L.; TURCO, R. F.; KONOPKA, A. E. Field scale variability of soil properties in Central Iowa soils. Soil Science Society of America Journal, New York, v. 58, n. 5, p. 1501-1511, 1994.

CAMPOS, M. C. C.; SOARES, M. D. R.; OLIVEIRA, I. A.; SANTOS, L. A. C.; AQUINO, R. E. Spatial variability of physical attributes in Alfisol under agroforestry, Humaitá region, Amazonas state, Brazil. Revista de Ciências Agrárias, Belém, v. 56, p. 149-159, 2013. https://doi.org/10.4322/rca.2013.023

CONAB - Companhia Nacional de Abastecimento. Perspectivas para a agropecuária, safra 2016/2017; abril/2017. Brasília: CONAB, 2017. Disponível em: V. 4 - SAFRA 2016/17 - N.7 - Sétimo levantamento ABRIL 2017

CONCENÇO, G.; CECCON, G. Ocorrência de espécies daninhas em função de sucessões de cultivo. Planta Daninha, Viçosa, v. 31, p. 359-368, 2013.

CUNHA, A. M.; LANI, J. L.; SANTOS, G. R.; FILHO, E. I. F.; TRINDADE, F. S.; SOUZA, E. Espacialização da precipitação pluvial por meio de krigagem e cokrigagem. Pesquisa Agropecuária Brasileira, Brasília, v. 48, n. 9, p. 1179-1191, 2013. https://doi.org/10.1590/S0100-204X2013000900001

FERRAZ, G. A. S.; SILVA, F. M.; CARVALHO, L. C. C.; ALVES, M. C.; FRANCO, B. C. Variabilidade espacial e temporal do fósforo, potássio e da produtividade de uma lavoura cafeeira. Engenharia Agrícola, Jaboticabal, v. 32, n. 1, p. 140-150, 2012.

FERRAZ, G. A. S.; SILVA, F. M.; OLIVEIRA, M. S.; AVELAR, R. C.; SALES, R. S. Variabilidade espacial da dose de $\mathrm{P}_{2} \mathrm{O}_{5} E \mathrm{~K}_{2} \mathrm{O}$ para adubação diferenciada e convencional em lavoura cafeeira. Coffee Science, Lavras, v. 10, n. 3, p. 346-356, 2015.

FERRAZ, G. A. S.; SILVA, F. M.; OLIVEIRA, M. S.; CUSTODIO, A. A. P.; FERRAZ, P. F. P. Variabilidade espacial dos índices fenológicos da planta de uma lavoura cafeeira. Revista Ciência Agronômica, Fortaleza, v. 48, n. 1, p. 81-91, 2017.

MARTINS, M. V.; CARVALHO, M. P.; ANDREOTTI, M.; MONTANARI, R. Correlação linear e espacial entre a produtividade do feijoeiro e atributos físicos de um Latossolo Vermelho distroférrico de Selvíria, Estado de Mato Grosso do Sul. Acta Scientiarum Agronomy, Maringá, v. 31, p.147-154, 2009.

https://doi.org/10.4025/actasciagron.v31i1.6641

MEGDA, M. M.; CARVALHO, M. P.; VIEIRA, M. X.; ANDREOTTI, M.; PEREIRA, E. C. Correlação linear e espacial entre a produtividade de feijão e a porosidade de um Latossolo Vermelho de Selvíria (MS). Revista Brasileira de Ciência do Solo, Viçosa, v. 32, p. 781-788, 2008. 
MONTANARI R.; PELLIN, D. M. P.; JÚNIOR, C. A. S.; CARVALHO, M. P.; GIOIA, M. T.; DALCHIAVON, F. C.; GONZÁLEZ A. P. Correlação entre produção de feijão e atributos físicos de um Latossolo em Mato Grosso do Sul. Revista Ceres, Viçosa, v. 60, p. 772-784, 2013 a. https://doi.org/10.1590/S0034-737X2013000400011

MONTANARI, R.; CARVALHO, M. P.; FILHO, M. C. M. T.; DALCHIAVON, F. C. Produção de matéria seca da braquiária de acordo com os atributos químicos de um Latossolo em Selvíria, Mato Grosso do Sul. Revista Ceres, Viçosa, v. 60, p. 772-784, 2013b.

MONTANARI, R.; PANACHUKI, E.; LOVERA, L. H.; CORREA, A. R.; OLIVEIRA, I. S.; QUEIROZ, H. A.; TOMAZ, P. K. Variabilidade Espacial da Produtividade de Sorgo e de Atributos do Solo na Região do Ecótono Cerrado-Pantanal, MS. Revista Brasileira de Ciência do Solo, Viçosa, v. 39, p. 385-396, 2015.

PIMENTEL-GOMES, F. P.; GARCIA, C. H. Estatística aplicada a experimentos agronômicos e florestais. Piracicaba: FEALQ, 2002. 309p.

SILVA, A. L. M. S.; MONTANARI R.; CARVALHO M. P.; LIMA E. S.; COSTA, N. R. Componentes de produção do feijão (Phaseolus vulgaris) correlacionados com índices fenológicos físicos de um Latossolo sob plantio direto em Selvíria-MS. II Simpósio de Geoestatística Aplicado em Ciências Agrárias, maio 2011.

SHAPIRO, S. S.; WILK, M. B. An analysys of variance test for normality: complete samples. Biometrika, London, v. 52, p. 591-611, 1965. https://doi.org/10.2307/2333709

https://doi.org/10.1093/biomet/52.3-4.591

SORATTO R. P.; SCHLICK, G. D. S.; FERNANDES, A. M.; OLIVEIRA, L. F. F. A. Crescimento e produtividade de duas cultivares de feijão em função de doses de ácido 2,3,5-triiodobenzoico. Ciência Rural, Santa Maria, v. 45, p. 2181-2186, 2015. https://doi.org/10.1590/0103-8478cr20140389

TRANGMAR, B. B.; YOST, R. S.; UEHARA, G. Application of geostatistics to spatial studies of soil properties. Advances in Agronomy, Amsterdã, v. 38, p. 45-94, 1985. 